\title{
Microbial Fuel Cells for Simultaneous Electricity Generation and Organic Degradation from Slaughterhouse Wastewater
}

\author{
Adrianus Kristyo Prabowo a, Agnes Priska Tiarasukmaa, Marcelinus Christwardanab, * \\ and Dessy Ariyantia,c
}

\author{
a Department of Chemical Engineering, Diponegoro University, Jl Prof. Soedharto, SH, Tembalang, Semarang, 50275, Indonesia \\ ${ }^{b}$ Graduate School of Energy and Environment, Seoul National University of Science and Technology, 232 Gongneung-ro, Nowon-gu, Seoul, 139-743, \\ Republic of Korea
}

${ }^{c}$ Center of Biomass and Renewable Energy (C-BIORE), Department of Chemical Engineering, Diponegoro University, Jl Prof. Soedharto, SH, Tembalang, Semarang, 50275, Indonesia

\begin{abstract}
Microbial fuel Cell (MFC) has gained much attention in recent years due to its capability in simultaneous organic decomposition and electricity generation. Here, self-fabricated MFCs system were used to generate electricity and to reduce organic pollutant contained in slaughterhouse wastewater. In order to investigate the MFC configuration for process optimization, the experiments were conducted by employing different types of electrode materials, electrode size, and substrate-rumen microbe's ratio. Results shows that configuration of MFC with graphite-copper electrode $31.4 \mathrm{~cm}^{2}$ (active surface), and substraterumen microbes ratio $1: 10$ shows the best result by producing $318 \mathrm{~mA} \mathrm{~m}^{-2}$ of current density, potential of $2.4 \mathrm{~V}$, and achieve maximum power density up to $700 \mathrm{~mW} \mathrm{~m}^{-2}$. In addition, self-fabricated MFC also shows its ability in reducing organic component by decreasing the chemical oxygen demand (COD) of the slaughterhouse wastewater to $67.9 \%$ and increasing the system $\mathrm{pH}$ from 5.9 to 7.5 which emphasize that MFC (operating at ambient condition $29^{\circ} \mathrm{C}$ ) can be used as an alternative green-technology for slaughterhouse wastewater treatment.
\end{abstract}

Keywords: microbial fuel cells, slaughterhouse wastewater, electricity generation, chemical oxygen demand, maximum power density

Article History: Received March 26, 2016; Received in revised form June 20, 2016; Accepted June 25, 2016; Available online

How to Cite This Article: Prabowo, A.K., Tiarasukma, A.P., Christwardana, M. and Ariyanti, D. (2016) Microbial Fuel Cells for Simultaneous Electricity Generation and Organic Degradation from Slaughterhouse Wastewater. Int. Journal of Renewable Energy Development, 5(2), $107-112$. http://dx.doi.org/10.14710/ijred.5.2.107-112

\section{Introduction}

Microbial fuel cell (MFC) is bio-electrochemical devices that use microbe as catalyst to convert organic and inorganic substrates into electrical current (Hubenova and Mitov, 2015; Prasad et al., 2007; Min and Logan, 2004; Babanova et al., 2011). The core principle of MFC is the metabolism process of microbe which consist of two steps. The first step requires the removal of electrons from organic matter degradation (oxidation), and the second step consists of giving those electrons to something that will accept them (reduction), such as oxygen or nitrate.
Microbe grown under anaerobic conditions (without the presence of oxygen) can transfer electrons to electrode (anode), which further generate the current and voltage to produce electricity. The system basically consists of substrate as organic source, microorganism as biocatalyst, proton exchange membrane and electrochemical device to collect the electron generated by the system. Although the achieved power and current densities generated by MFC are still very low, this technology is worth for further development as it can produce a sustainable energy from organic source such as waste.

Wastewater from petroleum industry, municipal, and agricultural have been successfully employed as a source for MFC substrate (Karthikeyan et al., 2016; Ge et al., 2015; Guo et al., 2016; Abbasi et al., 2016). In 
Citation: Prabowo, A.K., Tiarasukma, A.P., Christwardana, M. and Ariyanti, D. (2016). Microbial Fuel Cells for Simultaneous Electricity Generation and Organic Degradation from Slaughterhouse Wastewater. Int. Journal of Renewable Energy Development, 5(2), 107-112, doi : 10.14710/ijred.5.2.107-112

P a g e 108

addition, Heilmann and Logan (2006) also confirmed the possibility of using rich protein meat packing wastewater (MPW) as substrate and successfully reduce chemical oxygen demand (COD) and biological oxygen demand (BOD) value and at the same time generate electricity through MFC system. Slaughterhouse wastewater also possible to be used as MFC substrate as it contained various and high amounts of organic matter (e.g., proteins, blood, fat and lard) (Bazrafshan et al., 2012). COD and total organic carbon (TOC) values of slaughterhouse wastewater are up to $15900 \mathrm{ppm}$ and $1200 \mathrm{ppm}$ respectively (BustilloLecompte et al., 2015). Several works have been introduced in terms of employing MFC for slaughterhouse wastewater treatment by using different types of microbe, for instance Katuri et al. (2012) applied MFC using granular anaerobic sludge as microbe source. On the other hand, Elanthamilan et al. (2014) and Ghanapriya et al., (2012) employed MFC with wild anaerobic bacteria. Rumen microbe normally collected from ruminant animal which consists of mixture of bacteria, fungi, archaea, viruses, and protozoa with predominantly is anaerobic microbe (4060\%) and they can live at pH 5.5-6.5 (Dijkstra et al., 2005; Hobson and Stewart). This type of biocatalyst may be beneficial for improving the performance of MFC. So far, research on rumen microbe utilization for slaughterhouse wastewater treatment via MFC is rarely performed.

Generally, parameters that influence the process performance of MFC include electrochemical device configuration such as size and shape of electrodes, solutes in both chambers, arrangements of electrodes and proton exchange membrane available area for transporting solutes between anode and cathode, surface chemical properties of electrodes, electrode materials (Wang et al., 2011). Type of electrode material is one of the parameters that can affect with performance and productivity of the MFC. Physical and chemical stability which include resistance to corrosion, the formation of oxide or hydride particular, the rate and selectivity of the product to be formed, electrical conductivity, and the electrode resistance is a factor to consider in selecting electrode. According to Logan, the terms of good anode are high conductivity, noncorrosive, high specific surface area (area per volume), high porosity, not pollute, inexpensive, easy to use and can be used in large scale (Logan, 2008).

In this study, we investigated the effect of material type and size of electrode MFCs performance, COD and $\mathrm{pH}$ values of slaughterhouse wastewater before and after the degradation process via MFC by using rumen microbe as biocatalyst. We emphasize that in spite of our extensive inquiry, the slaughterhouse wastewater treatment by using rumen microbe as MFC fuel has hardly reported. Based on that, we anticipate that our study will be a cornerstone to establish a baseline protocol of MFC.

\section{Materials and Methods}

\subsection{Materials}

Slaughterhouse wastewater (the primary clarifier overflow) and multicultural rumen microbe were collected from a local slaughterhouse factory (Semarang, Indonesia) without any filtration. The slaughterhouse wastewater characteristic and composition can be shown in Table 1 . The average $\mathrm{pH}$; total dissolve solids (TDS); and chemical oxygen demand (COD) in raw wastewater were 5.9; 983 ppm and 9858 ppm, respectively. $\mathrm{KMnO}_{4}$ and $\mathrm{H}_{2} \mathrm{SO}_{4}$ were purchased from Sigma Aldrich (St Louise, USA). $\mathrm{K}_{2} \mathrm{Cr}_{2} \mathrm{O}_{7}$ was purchased from Merck (Massachusetts, USA).

Table 1

Characteristic and Composition of Slaughterhouse Wastewater

$\begin{array}{ccc}\text { Parameter } & \text { Value } & \text { Unit } \\ \text { pH } & 5.9 & - \\ \text { TDS } & 983 & \text { ppm } \\ \text { DO } & 1.03 & \text { ppm as } 0_{2} \\ \text { COD } & 9858 & \text { ppm as } \mathrm{O}_{2} \\ \text { BOD } & 5348 & \text { ppm as } \mathrm{O}_{2} \\ \text { Total-N } & 392 & \text { ppm as N } \\ \text { Alkalinity } & 530 & \mathrm{ppm}\end{array}$

\subsection{Rumen Microbe Incubation and Electrolyte Preparation}

Rumen microbes were used as biocatalyst in anodic chamber. Slaughterhouse wastewater which act as a substrate was mixed with rumen microbes ratio $1: 10 ; 10: 1 ;$ and $1: 1 \mathrm{v} / \mathrm{v}$. Incubation was conducted for 120 hours at $28-30^{\circ} \mathrm{C}$. Incubated slaughterhouse wastewater and rumen microbes were placed in anode chamber and $1 \mathrm{~L}$ of $1 \mathrm{M} \mathrm{KMnO}_{4}$ was placed in cathode chamber as electrolyte.

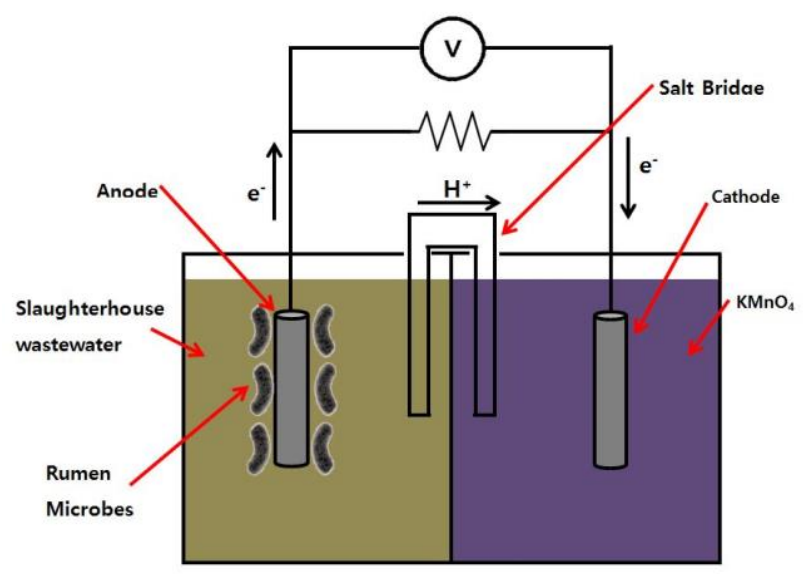

Fig. 1 Construction of Microbial Biofuel Cell by using Multicultural Rumen Microbes. 


\subsection{Bioreactor Construction}

Self-fabricated dual chamber MFC reactor was used in this experiment (Figure 1). It has $150 \mathrm{~mm}$ length, $150 \mathrm{~mm}$ width, and $150 \mathrm{~mm}$ height and it was operated under ambient temperature and pressure.

Both anode and cathode plate were placed on each chamber (1L volume). Salt bridge was used as proton exchange system between two chambers, anodic and cathodic chamber. It was prepared by mixing saturated $\mathrm{NaCl}$ and agar, and then fed in the pipe that connecting the anodic and cathodic chamber. Good sealing is necessary to prevent any leaked in the joint connection between chamber and salt bridge.

Several types of electrode materials (Zinc, graphite, and Copper) were used as cathodes with only graphite as anode material. This electrode has various sizes; 7.8, 15.7, and $31.4 \mathrm{~cm} 2$. Prior experiment, graphite electrode, was treated to remove impurity inside graphite electrode (Deepika et al., 2015). Graphite electrode was soaked with $1 \mathrm{M} \mathrm{HCl}$ and $1 \mathrm{M}$ $\mathrm{NaOH}$ overnight before and after experiment, and then washed with H20. Multimeter (SUNWA YX-1000A) was connected to each electrode to measure current and voltage. The MFC was operated for 120 hours, enough for anolyte containing multicultural rumen microbes produce the electron, and then followed by current and potential measurement. The anolyte was used without any replacing fresh substrate.

\subsection{Chemical and Electrochemical Measurements}

Acidity measurements were performed at the beginning and end of batch experiment for each variable by using a $\mathrm{pH}$ meter (HM TDS-3, USA). Organic content of anolyte was analysed at the same time via chemical oxygen demand (COD) measurement using spectrophotometer (Optima SP-300, Japan) followed colorimetric method (LaPara et al., 2000). Currents and potential generated from the process were measured using a multimeter (SUNWA YX-1000A, Japan). Power density analysis was calculated by Potential and Current Density ( $\mathrm{P}=\mathrm{V} \times \mathrm{I}$ ) with the resistance was set around 1 $\mathrm{K} \Omega$. Data was collected every 6 hours for 120 hours incubation process.

\section{Results and Discussion}

\subsection{Electricity generation}

Copper, graphite, and zinc were used as cathodes with only graphite as anode material. Electrode material is important that determine the performance of MFC as different material generated different electrical energy and potential. Figure 2a-b shows the graphite-copper electrode combination produce highest current density $236 \mathrm{~mA} \mathrm{~m}^{-2}$ and potential $1.2 \mathrm{~V}$ compare to other materials (zinc-graphite was $191 \mathrm{~mA} \mathrm{~m}^{-2}, 0.7 \mathrm{~V}$ and graphite-graphite was $203 \mathrm{~mA} \mathrm{~m}-2,0.9 \mathrm{~V}$ ). $\mathrm{Cu}$ has potential standard $\left(\mathrm{E}^{\circ}\right)$ value higher than $\mathrm{Zn}$ with $+0.337 \mathrm{~V}$ and $-0.763 \mathrm{~V}$ respectively. It means that $\mathrm{Cu}$ can accept more electron than $\mathrm{Zn}$, as it favored electron transfer from anode to cathode and produce higher power density. Zn was susceptible to corrosion that causes impurities in the electrode. These impurities might cover the surface of $\mathrm{Zn}$ and inhibit cathode to accept electron from anode which lead to low power density production. Copper also proved as an outstanding cathode material in other research conducted by Deepika et al., which shows highest output voltage and current compared with other five different materials of anode (Deepika et al., 2015).
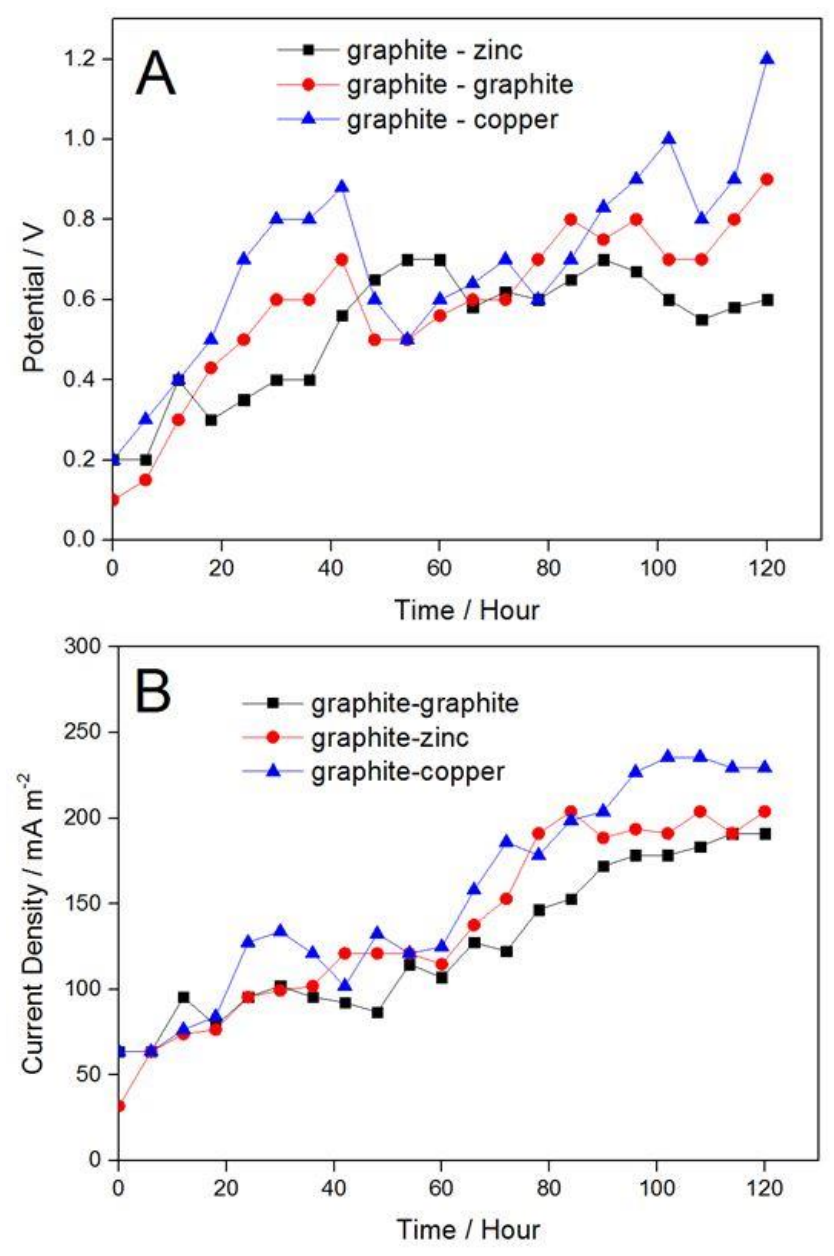

Fig. 2 Comparison (a) Potential and (b) current density of different materials used as cathode graphite, zinc, and copper

Surface area or electrode size is also an important parameter in determining the MFC configuration of certain system. By increasing the electrode size means providing larger surface area for microbe to transfer the electrons and by then can increase the power density produced from the MFC system. Figure 3a-b shows the trend line of potential and current density produced 
during the observed process at 120 hours in different size of electrodes. As expected, electrode with highest surface area $31.4 \mathrm{~cm}^{2}$ produced highest current density with value was $270 \mathrm{~mA} \mathrm{~m}^{-2}$ and potential with value $1.42 \mathrm{~V}$. Size of electrode $15,7 \mathrm{~cm}^{2}$ generated $236 \mathrm{~mA} \mathrm{~m}^{-2}$, $1.2 \mathrm{~V}$ while the smallest one $7.8 \mathrm{~cm}^{2}$ generated $205 \mathrm{~mA}$ $\mathrm{m}^{-2}, 0.4 \mathrm{~V}$. As mentioned previously, surface area is important part of electron transfer in MFC system. Higher surface area provides larger contacting surface that favored the electron transfer from microbe to the electrochemical device. As already reported in other research, the higher size of electrode could produce the higher current density and potential (Qian and Morse, 2011).
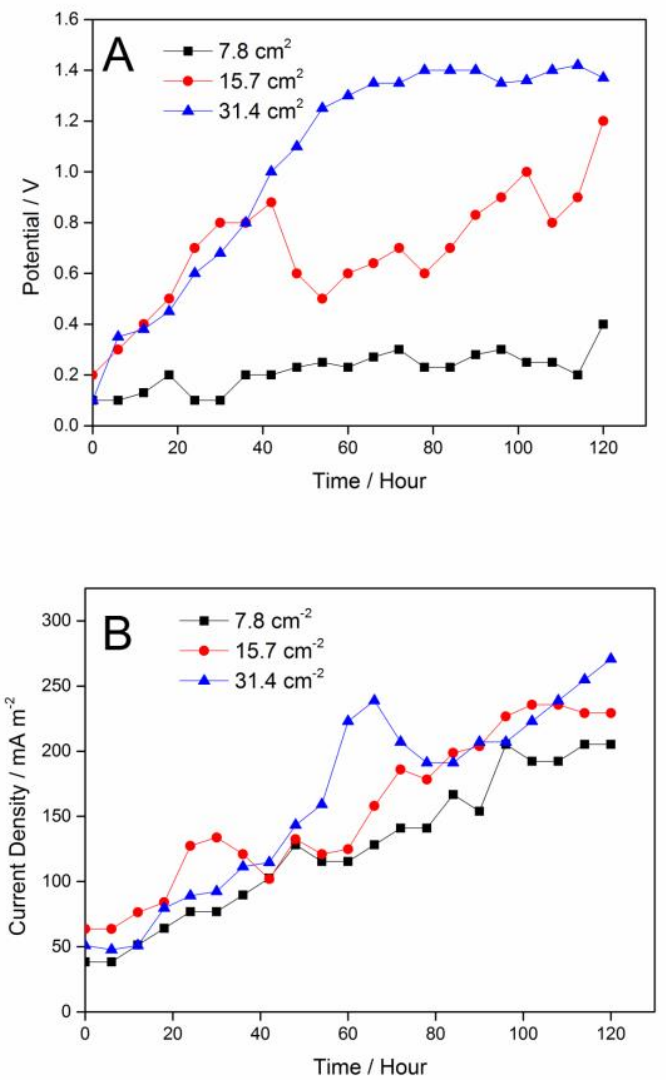

Fig. 3 Comparison (a) Potential and (b) current density of different sizes of electrodes $7.4,15.7$, and $31.4 \mathrm{~cm}^{2}$

The phenomena that take place in a MFCs are complex as many biological, physical-chemical and electro-chemical processes are involved. Biological process, including the metabolism and the growth of microbe. Preliminary observation was finding out the optimum ratio of the substrate and microbe as biocatalyst. For the test, mixed substrate-rumen microbes with ratios $1: 10,10: 1$, and 1:1 were used with optimum electrode configuration $31.4 \mathrm{~cm} 2$ of graphitecopper. Figure 4a-b depict substrate- rumen microbes with ratio 1:10 produce highest power density compared to other ratio. Substrate- rumen microbes with ratio $10: 1,1: 1$, and $1: 10$ generate current density value $172,270,318 \mathrm{~mA} \mathrm{~m}^{-2}$ and potential value 0.75 , $1.42,2.4 \mathrm{~V}$ respectively. Microbes need sufficient food to growth, and in this particular system (slaughtered wastewater: rumen microbes with) the ratio of substrate 1 to 10 rumen microbes with produced highest power density. Excessive substrate may not beneficial for the process, as putting equal ratio in the process only give less potential that lead to lower power density generation. In addition, putting huge amount of substrate (10:1) may not beneficial as it could inhibit the electron transfer from microbes system to the electrode surface.
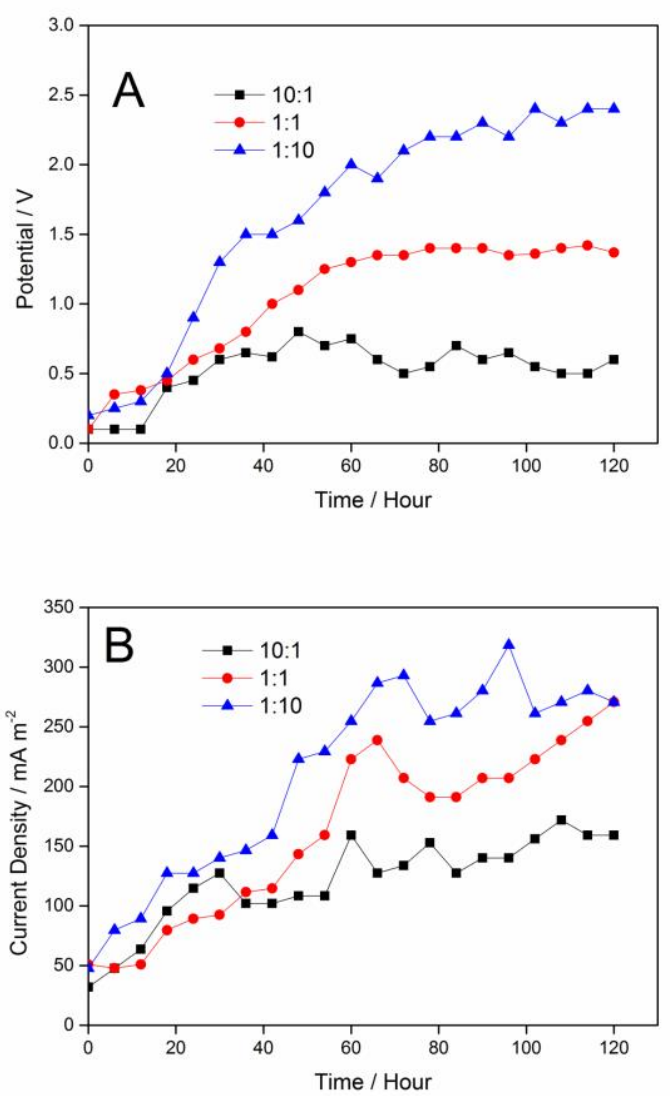

Fig. 4 Comparison (a) Potential and (b) current density of different substrate- rumen microbes with ratio: 1:10, 1:1, and 10:1

\subsection{Organic degradation}

From the previous section, it can be stated that for this particular system and particular research framework the maximum power density that can be generated is $700 \mathrm{~mW} \mathrm{~m}^{-2}$ (Figure 5). It is higher than other MFC research, for instance COD removal by using single chamber MFC reactor with graphite electrode was $26 \mathrm{~mW} \mathrm{~m}^{-2}$ (Liu et al., 2004), utilization of olive mill wastewater by using single chamber MFC reactor with platina electrode was $124.6 \mathrm{~mW} \mathrm{~m}^{-2}$ (Sciarria et al., 
2013), and utilization of alcohol distillery wastewater by using anaerobic fluidized bed MFC reactor with carbon fiber paper was $124.03 \mathrm{~mW} \mathrm{~m}^{-2}$ (Huang et al., 2011).

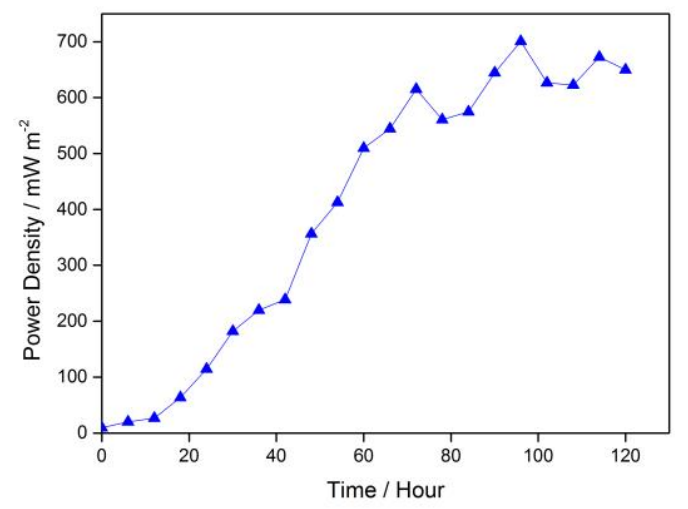

Fig. 5 The optimum configuration of MFC with graphite and copper electrode $31.4 \mathrm{~cm}^{2}$ in size and substrate- rumen microbes with ratio 1:10 that can reduce COD value and neutralize $\mathrm{pH}$ of system

The steep trend line of potential and current density observed from 0 to 80 hours is due to rumen microbe's growth along the time by following growth mechanism which need to be investigate further. Extracting from the graph it can also be observed that the growth reached it maximum value from 80-120 hours which might be due to no more substrate that could be degrade to generate electricity.

Lack of substrate at the end of the process means that organic degradation did happened. To prove that, the measurement of COD value was conducted. We investigated the performance of rumen bacteria to remove COD inside slaughterhouse wastewater. For the test, we used the optimum parameter with $31.4 \mathrm{~cm} 2$ graphite-copper electrode and substrate-microbes ration 1:10. From the experiment, multicultural rumen microbes in MFC could reduce COD up to $67.9 \%$ (from $10815 \mathrm{ppm}$ to $3472 \mathrm{ppm}$ ). Microbes have capability to reduce higher concentration of COD by way of synthesizing enzyme themselves (del Campo et al., 2012). COD reduction occurred due to the activity of microbes that utilize organic substrates, especially carbon for metabolism. COD reduction would lead to a decrease in electron production due to the amount of organic content would be reduce. Microbes can adhere in anode, so increasing area of anode affected to increasing of electron generation and reducing of COD (Alatraktchi et al., 2011).

Beside COD, $\mathrm{pH}$ of the system before and after the process was also investigated. The acidity of mixture solution increased from 5.9 to 7.5. In MFC mechanism, electrons were captured by anode and transferred to the cathode via external circuit, while protons that are generated from oxidation of substrates should be transferred to cathode via salt bridge to cathode. We indicate that the rate of proton transferred to cathodes is faster than proton generation in anode. The fast consumption of protons leads the increasing $\mathrm{pH}$ of wastewater. This is opposite from research that was conducted by Karthikeyan et al., (2016) where the protons generation rate faster than the protons consumption in the cathode, so that the $\mathrm{pH}$ decreases.

\subsection{Simple modelling of power density}

Modeling is a powerful tool for the in-depth study and optimization of MFC. A model is basically aimed at describing MFC performance based on certain laws and equations. The complexity of any model depends on different factors such as the dimension selected, the assumptions made and the level of detail used in describing the processes involved. Study of the phenomena that take place in an MFC covers a wide range of processes, from mass transport through the cell, the phases of matter considered and the boundary conditions, to microbial growth, the anode and cathode reaction kinetics and the electrochemical behavior of the system. The robustness of a model will be judged by its predictive capacity and the balance between the computation time needed and the precision of the results (Ortiz-Martinez et al., 2015).

Generated from the data observed, the only modelling that can be draw is the power density modelling. As power density of the experimental data can be calculated using $\mathrm{P}=\mathrm{V} \times \mathrm{I}$ and $\mathrm{V}=\mathrm{I} \times \mathrm{R}$, where $\mathrm{P}$ is power density $\left(\mathrm{mWm}^{-2}\right), \mathrm{V}$ is the potential $(\mathrm{V})$ and $\mathrm{I}$ is current density $\left(\mathrm{mAm}^{-2}\right)$. While modelling data of power density can be calculated using $\mathrm{P}=\mathrm{I}^{2} \mathrm{x} R$ where $\mathrm{P}$ is power density $\left(\mathrm{mWm}^{-2}\right), \mathrm{R}$ is the resistance and $\mathrm{I}$ is current density $\left(\mathrm{mAm}^{-2}\right)$, with assumption the resistance in experimental and modelling is constant. The comparison between experimental data and model can be observed in Figure 6. The experimental data is nearly fit into equation model $y=0.00736 \mathrm{x}^{2}\left(\mathrm{R}^{2}=0.96\right)$.

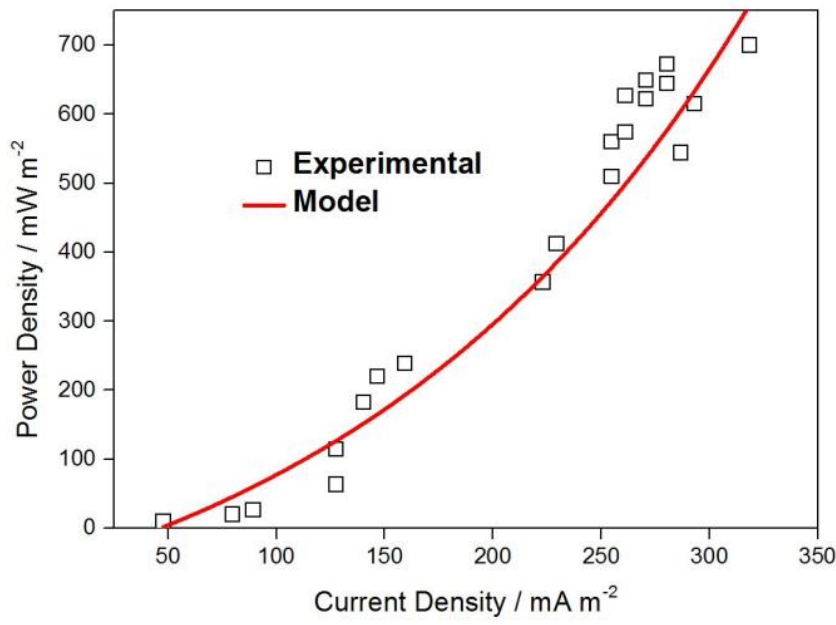

Fig. 6 The experimental and modelling correlation between current density and power density from optimum configuration of MFC 


\section{Conclusion}

Slaughterhouse wastewater treatment via MFC by employing rumen microbes with as biocatalyst has been successfully conducted with electricity as by product. Configuration of MFC with graphite-copper electrode $31.4 \mathrm{~cm}^{2}$ in size, and substrate-rumen microbes with ratio $1: 10$ shows the optimum result with current density of $318 \mathrm{~mA} \mathrm{~m}^{-2}$, potential $2.4 \mathrm{~V}$, and maximum power density up to $700 \mathrm{~mW} \mathrm{~m}^{-2}$. In addition, selffabricated MFC operating at ambient condition $\left(29^{\circ} \mathrm{C}\right.$ and $\mathrm{pH}$ 7.5) also shows its ability in reducing organic component by measuring the chemical oxygen demand (COD) up to $67.9 \%$ followed by increasing pH from 5.9 to 7.5. The correlation between current density and power density in experimental is nearly fit with equation model $\mathrm{y}=0.00736 \mathrm{x}^{2} \quad\left(\mathrm{R}^{2}=0.96\right)$. It all emphasize as a green-technology for slaughterhouse wastewater treatment with further improvement in process efficiency.

\section{Acknowledgments}

The authors thank to the Wastewater Laboratory, Department of Chemical Engineering, Diponegoro University for their facilities and assistances

\section{References}

Abbasi, U., Jin, W., Pervez, A., Bhatti, Z. A., Tariq, M., Shaheen, S., Iqbal, A., \& Mahmood, Q. (2016) Anaerobic microbial fuel cell treating combined industrial wastewater: Correlation of electricity generation with pollutants. Bioresour Technol, 200,1-7.

Alatraktchi, F. A., Zhang, Y., Noori, J. S., \& Angelidaki. I. (2012) Surface area expansion of electrodes with grass-like nanostructures and gold nanoparticles to enhance electricity generation in microbial fuel cells. Bioresour. Technol, 123, 177-183

Babanova, S., Hubenova, Y., \& Mitov, M. (2011) Influence of artificial mediators on yeast-based fuel cell performance. J. Biosci. Bioeng, 112, 379-387.

Bazrafshan, E., Kord Mostafapour, F., Farzadkia, M., Ownagh, K. A., \& Mahvi, A. H. (2012) Slaughterhouse wastewater treatment by combined chemical coagulation and electrocoagulation process. PLOS ONE, 7, 1-7

Bustillo-Lecompte, C. F \& Mehrvar, M. (2015) Slaughterhouse wastewater characteristics, treatment, and management in the meat processing industry: A review on trends and advances. J. Environ. Manage, 161, 287-302

Clauwaert, P., Aelterman, P., Pham, T. H., Schamphelaire, L., Carballa M., Rabaey, K., \& Verstraete, W. (2008) Minimizing losses in bioelectrochemical systems: the road to applications. Appl. Microbiol. Biotechnol, 79, 901-913.

Deepika, J., Meignanalakshmi S., \& Thilagaraj. R. W. (2015) The Optimization of Parameters for Increased Electricity Production by a Microbial Fuel Cell Using Rumen Fluid. Int J. Green Energy, $12,333-338$

del Campo, A. G., Lobato, J., Cañizares, P., Rodrigo, M.A., \& Fernandez Morales, F.J. (2012) Short-term effects of temperature and COD in a Microbial Fuel Cells. Appl. Energy, 101, 213-217

Dijkstra, J., Forbes, J.M., \& France. J. (2005) Quantitative Aspects of Ruminant Digestion and Metabolism, 2nd edition. Wallingford, Oxfordshire, CABI Publishing. UK

Elanthamilan, E., Merlin, J. P., Sarala, L., \& Sathiyan, A. (2014) Mediatorless Microbial Fuel Cell with Nafion-115 and Salt bridge as Proton Exchange Membrane. India J Appl Res, 4, b1-3
Ge, Z., Wu, L., Zhang, F., \& He, Z. (2015) Energy extraction from a largescale microbial fuel cell system treating municipal wastewater. J. Power Sources, 297, 260-264.

Ghanapriya, K., Rana S., \& Kalaichelvan. P.T. (2012) Electricity Generation from Slaughterhouse Wastewater using Microbial Fuel Cell Technology. Adv. Bio Tech, 11, 20-23.

Guo, X., Zhan, Y., Chen, C., Cai, B., Wang, Y., \& Guo. S. (2016) Influence of packing material characteristics on the performance of microbial fuel cells using petroleum refinery wastewater as fuel. Renewable Energy, 87, 437-444.

Heilmann, J. \& Logan, B.E. (2006) Production of electricity from proteins using a microbial fuel cell. Water Environ. Res, 78, 531537.

Hobson, P.N. \& Stewart, C.S. (1997) The Rumen Microbial Ecosystem, 2nd edition, New York: Springer, USA

Huang, J., Yang, P., Guo, Y., \& Zhang, K. (2011) Electricity generation during wastewater treatment: An approach using an AFB-MFC for alcohol distillery wastewater. Desalination, 276, 373-378.

Hubenova, Y \& Mitov, M. (2015) Extracellular electron transfer in yeast-based biofuel cells: A review. Bioelectrochemistry, 106, 177-185

Karthikeyan, R., Selvam, A., Cheng, K. Y., \& Wong, J. W. (2016) Influence of ionic conductivity in bioelectricity production from saline domestic sewage sludge in microbial fuel cells," Bioresour. Technol, Vol 200, 845-852

Katuri, K. P., Enright, A. M., O'Flaherty, V., \& Leech, D. (2012) Microbial analysis of anodic biofilm in a microbial fuel cell using slaughterhouse wastewater. Bioelectrochemistry, 87, 164-171

LaPara, T. M., Alleman, J. E., \& Pope. P.G. (2000) Miniaturized closed reflux, colorimetric method for the determination of chemical oxygen demand. Waste Manage, 20, 295-298

Liu, H., Ramnarayanan, R. \& Logan B.E. (2004) Production of Electricity during Wastewater Treatment Using a Single Chamber Microbial Fuel Cell. Environ. Sci. Technol, 38, 22812285.

Logan, B.E. (2008) Microbial Fuel Cell”, John Wiley \& Sons, Inc., Hoboken, New Jersey, USA

Lovley, D. R. (2008) The microbe electric: conversion of organic matter to electricity. Curr. Opin. Biotechnol, 19, 564-571.

Min, B \& Logan, B.E. (2004) Continuous Electricity Generation from Domestic Wastewater and Organic Substrates in a Flat Plate Microbial Fuel Cell. Environ. Sci. Technol, 38, 5809-5814.

Ortiz-Martínez, V.M., Salar-García, M.J., de los Ríos, A.P., HernándezFernández, F.J., Egea, J.A., Lozano, L.J. (2015) Developments in microbial fuel cell modeling. Chem. Eng. J, 271, 50-60.

Prasad, D., Arun, S., Murugesan, M., Padmanaban, S., Satyanarayanan, R.S., Berchmans, S., \& Yegnaraman, V. (2007) Direct electron transfer with yeast cells and construction of a mediatorless microbial fuel cell. Biosens Bioelectron, 22, 2604-2610.

Qian, F. \& Morse, D.E. (2011) Miniaturizing microbial fuel cells. Trends Biotechnol, 29, 62-69.

Richter, H., Nevin, K., Jia, H., Lowy, D., Lovley, D. R., \& Tender, L. (2009) Cyclic voltammetry of biofilms of wild type and mutant Geobacter sulfurreducens on fuel cell anodes indicates possible roles of $\mathrm{OmcB}, \mathrm{OmcZ}$, type IV pili, and protons in extracellular electron transfer. Energy Environ. Sci, 2, 506-516

Sciarria, T. P., Tenca, A., Epifanio, A. D., Mecheri, B., Merlino, G., Barbato, M., \& Adani, F. (2013) Bioresource Technology Using olive mill wastewater to improve performance in producing electricity from domestic wastewater by using single-chamber microbial fuel cell. Bioresour. Technol, 147, 246-253.

Venkatamohan, S., Veerraghuvulu, S., \& Sarma, P. N. (2008) Biochemical evaluation of bioelectricity production process from anaerobic wastewater treatment in a single chambered microbial fuel cell (MFC) employing glass wool membrane. Biosens. Bioelectron, 23, 1326-1332.

Yokoyama, H., Ohmori, H., Ishida, H., Waki, M., \& Tanaka, Y. (2006) Treatment of cow-waste slurry by a microbial fuel cell and the properties of the treated slurry as liquid manure. Animal Sci. J. $77,634-638$. 